\title{
Digital Libraries and the Breakthrough in Linguistic Chronologization. The Applications of Digitization in Linguistics
}

\author{
Piotr Nowak \\ ORCID 0000-0001-8027-2396 \\ Department of Information Linguistics, Institute of Linguistics, \\ Adam Mickiewicz University in Poznan, Poland \\ Piotr Wierzchoń \\ ORCID 0000-0002-7658-5362 \\ Department of Korean Philology, Institute of Linguistics, \\ Adam Mickiewicz University in Poznan, Poland
}

\begin{abstract}
Purpose/Thesis: The turn of the century marked a beginning of the dynamic growth of Polish digital libraries. The process had results beyond the increased accessibility of library resources. From the perspective of information science, a digital library has many functions aside from sharing its resources; therefore, it is important that we attend to the role such libraries play in research conducted by scholars of different disciplines.

Approach/Method: This article is a review. The authors briefly present the role of digital libraries in applied linguistics, primarily in linguistic chronologization, i.e dating and re-dating of neologisms, with a focus on twentieth-century Polish language.

Results and conclusions: The analysis shows that the development of digital libraries was the condition sine qua non for establishing contemporary linguistic chronologization theory (which may be also considered to be a research method). The future growth of digital resources will allow the scholars to pose more plausible hypotheses regarding linguistic chronologization.

Originality/Value: Linguistic chronologization theory (TLCH) often features in linguistics scholarship. As far as the authors know, no information science journal published a paper considering the role of digital libraries in applied linguistics.
\end{abstract}

\section{Keywords}

Applied linguistics. Digital libraries. Digitization of library resources. Information science. Linguistic chronologization.

Received: 22 May 2020. Reviewed: 5 June 2020. Revised: 25 July 2020. Accepted: 30 September 2020.

\section{Introduction}

"Interdisciplinarity" is a term often mentioned (and over-interpreted) in scholarship. It has become common, not to say - fashionable - in the discourse of Polish humanities scholars. Of course, to claim that there is a need for interdisciplinary research is not to conduct it, or to gain genuinely interdisciplinary knowledge on such research's basis. We will refrain from discussing theoretical conditions for interdisciplinarity, but we will attempt 
to present specific studies which we consider interdisciplinary. Its culmination - modest, but eloquent - shall be an articulation of a linguistic chronologization hypothesis of the neologism "interdisciplinarity". We will explain "how it's done" below, highlighting the extraordinary importance of Polish digital libraries for the study of linguistics.

\section{Origins and functions of the digital libraries}

As our readers may guess, there were many reasons to develop digital libraries, but the primary aim of the process was to preserve the most valuable collections. A further aim was to increase access to the libraries' resources, or at least, make them more accessible than the undigitized resources. The digitization of the library resources greatly reduced the previously enormous costs of conservation and safe handling of valuable objects. It does not have any serious limitations, as objects of almost all types might be transferred into the digital world, and thus shared. Finally, it avoids the inherent limitations of "traditional" access: a single object might be viewed by an unlimited number of people at the same time (Kowalska, 2006).

These qualities of digitization made it rather fashionable. It should come as no surprise that the comparatively advanced technology, which the process required from previously traditional libraries, was first introduced in the more developed countries. The libraries in the USA were the pioneers of digitization. When it came to Europe, the first countries that digitized the resources of their libraries were France, Spain, and Germany; Czech Republic and Hungary in Central Europe (Kowalska, 2006).

General digitization arrived to Poland later; however, its rate was only slightly slower than in the leading countries of the region. First digital libraries in Poland were established on the cusp of 2001 and 2002 (Polish Internet Library, Wielkopolska Digital Library). According to Małgorzata Kowalska's early report on the digitization in Poland, 25 libraries digitized their resources by the end of 2003; out of 55 libraries constituting the national library resource, 14 conducted the necessary work in their own digitization labs. As far as the size of the digitized collections is concerned, about 10 thousand objects have been digitized (Kowalska, 2006).

In the following years, the rate of digitization grew. It is estimated that by the end of 2016, there were 120 digital libraries and repositories in Poland (Osińska et al., 2017, 5). In 2007, Polish Digital Libraries Federation (FBC, n.d.), a website collecting Polish digital libraries, providing access to almost 7 million objects was established.

\section{Methods of dating Polish neologisms before formulating the linguistic chronologization theory}

Later generations of humanities scholars constructed a research framework which, unlike the frameworks used in more theoretical disciplines, retained traditional (manual, introspective) premises. In the general understanding prevailing towards the end of the last century, "traditional" meant non-digital, i.e., lacking digital research tools.

The study of linguistic chronologization was conducted with the use of this framework. An analysis of the text required an enormous number of hours spent in the library, which resulted in a proportionally high number of errors. Thus conducted, research could not yield 
highly plausible hypotheses (its aims were too ambitious), as it did not cover statistically significant corpuses. This was impossible, because the traditional methods available to a humanities scholar did not allow for processing large amounts of data. Therefore, at the beginning of this century Hanna Jadacka could suggest that motyczkowanie was a neologism which had appeared after the Second World War, because the research conducted with a "traditional" method had not allowed her to pose any other hypothesis (Jadacka, 2001).

If scientific progress is nothing but a radical or dramatic refutation of previous hypotheses or theories, then, considering that Jadacka formulated her hypothesis basing on research conducted with "traditional" methods (which did not allow precise estimations of linguistic chronologization), we might suspect that her hypothesis did not correspond to the reality as closely as she would have wished. More erroneous linguistic chronologizations were posed basing on such uncertain premises. To save our readers a lengthy survey, we will consider Jadacka's work as a representative example. Alongside motyczkowanie, she considered following terms to be post-war neologisms:

autokontrola (Jadacka 2001, 97),

odmianoznawstwo (58),

ofensywność (187),

podatnicy (104),

podkategoria (90),

and many other lexical units.

Certain methodologists say that the reconstruction of humanities scholars' framework involves a transformation of a study into a lab. Therefore, the lab requires a complete reconstruction of humanities, which borrows categories from other disciplines to become a "science". The text studied in a lab is not a text, but a data sample (Pawlicka, 2017). Therefore, after a move from a "study" to a "lab", we may refute the dating of all post-war neologisms, because, although the laborious reading of the text, which was the basis of research in a study, suggested that they were post-war neologisms, the analysis of data processed in a lab shows that these terms functioned before the war; in one case, as far back as in the nineteenth century.

\section{Linguistic chronologization theory}

We employ the term "linguistic chronologization theory" because it has been used in research and resulting publications since 2008, but there is no reason the readers should not consider it a method, or even a technique. It is a matter of secondary importance. If preliminary research clearly shows significant disparities between the previous dating of a neologism and the factual time of its emergence then, obviously, a new linguistic chronologization theory, based on now available tools, is required. Following the suggestion of Jan Warzyńczyk, among others, it was funded on the cusp of the second decade of the twenty-first century (Wierzchoń, 2008), as it was agreed that the previous Polish linguistic chronologizations were outdated (inefficient) in their premises and applications. Their critics held that the material these theories relied on was not representative, and therefore they could not continue to yield reliable hypotheses regarding the emergence and evolution of neologisms (Wierzchon, 2013).

This objection to the previous linguistic chronologization theories is related to another: all datings were based only on two dictionaries published after the war. The first was edited 
by Witold Doroszewski; the second - by Mieczysław Szymczak. The outdated linguistic chronologization theories accepted as their premise the that words absent from these dictionaries, but present in texts published after 1945, were post-war neologisms. This method neglected vocabulary which might have featured in a Supplement to the Warsaw Dictionary ${ }^{1}$ which comprised approximately 60 thousand entries. Unfortunately, the Supplement was lost during the Second World War.

The dynamic development of digital libraries mentioned above filled this gap. The digitization, increasing on a daily basis, allowed:

(1) research, which resulted in a new program of linguistic chronologization;

(2) revision of the rules of Polish neologisms;

(3) formulation of a methodology for explaining phenomena occurring in Polish language (Graliński, 2019, Wierzchoń, 2013).

As a result, we may formulate a model of linguistic chronologization theory (TLCH), which allows us to answer the following question:

\begin{abstract}
Why does a scholar S, to realize an aim A in model M, assuming a system of values and beliefs S, employ in their chronologization grammar $\mathrm{G}$ in the year $\mathrm{Y}$, distant from the year of capacity $\mathrm{C}$ as regards the completion of the task, the series of premises $\mathrm{P}_{1}, \mathrm{P}_{2}, \mathrm{P}_{\mathrm{n}}$, resulting in chronologization $\mathrm{H}$ of a lexical unit $\mathrm{U}$, following the neologism rule $\mathrm{N}$, overcoming obstacle $\mathrm{O}$, ignoring a class of evident warnings W, formulated by authority A and taking into consideration advice $\mathrm{D}$, resigning from the previous tradition of conducting research of this type, T, and benefiting from support S (Wierzchoń, 2013).
\end{abstract}

In other words: why somebody concluded that motyczkowanie is a post-war, rather than pre-war, neologism.

TLCH comprises two elements. Its first element is theoretical, i.e. (1) the described object and, (2) the parameters of description. The parameters of description are identical to the dimensions of lexical units described. These dimensions might be grouped as follows:

- units of language (morphological, unit-word-semantical, unit-phrasematic-semantical, of the linguistic product, syntaxemic, of syntaxemic valency, of the part of speech, of valency of the part of speech, lexical);

- time (minute, hour, time of the day, day of the week, working / free day, summer suspension of socio-political life, week of the month, month, year, epoch, cyclicality);

- geographical location (city, district, countryside, country, continent);

- position in the text (pagination, layout).

Each of these dimensions has its characteristics. The characteristics of the dimension "day of the week" will be Monday, Tuesday, Wednesday, and so on; of the dimension "country" USA, France, Switzerland; "parts of speech" - adjective, verb, noun, and so on.

The second element of linguistic chronologization theory is its application, i.e. identification and extraction of the units containing the information regarding the time of publication from the digitized texts available in digital libraries, followed by photo - documentation (including the context). The process of identification might involve collecting thematic information of encyclopedic (general knowledge), or linguistic (knowledge of language, vocabulary, etc.) type. A browser of digital libraries' resources was constructed to facilitate research. This article bases on an analysis of c. $50 \%$ of the collections made available by Polish digital libraries

${ }^{1}$ Stownik języka polskiego edited by Jan Karłowicz, Adam Kryński and Władysław Niedźwiedzki, published in eight volumes in 1900-1927. 
(approximately 3 million of open access objects). The image files were translated into text with the help of the DjVuLibre package (http://djvu.sourceforge.net), and the entirety of the data (including metadata) was indexed using the Linux platform Apache Solr (https://lucene. apache.org/solr or https://www.elastic.co/). All resources were found in public domain.

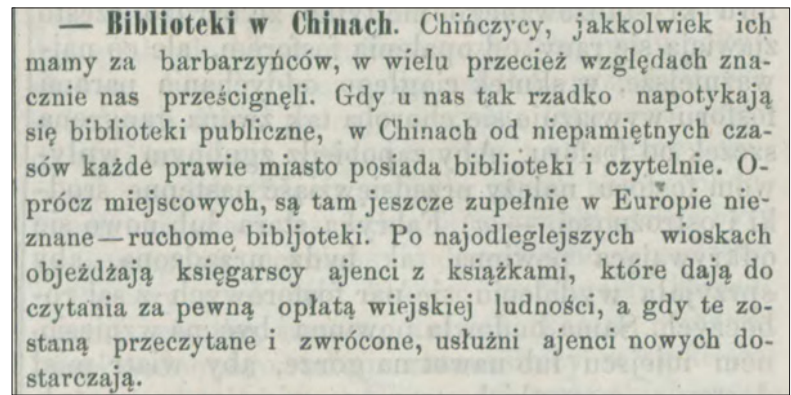

[Translation: Libraries in China. Chinese, no matter how savage we might think them, are in many ways our superiors. While here public libraries are a rarity, in China, from time immemorial, each city boasts libraries and reading rooms. Next to the stationary libraries, there are mobile libraries - virtually unknown in Europe. Library agents reach the most remote villages, lending books to the rural communities for a small sum, and when these are read and returned, the solicitous agents supply new ones].

Source:

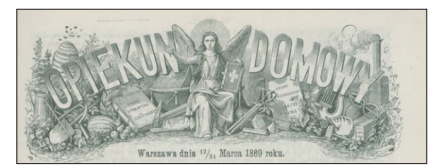

Opiekun Domowy, Warsaw, 13/24 March, 1869.

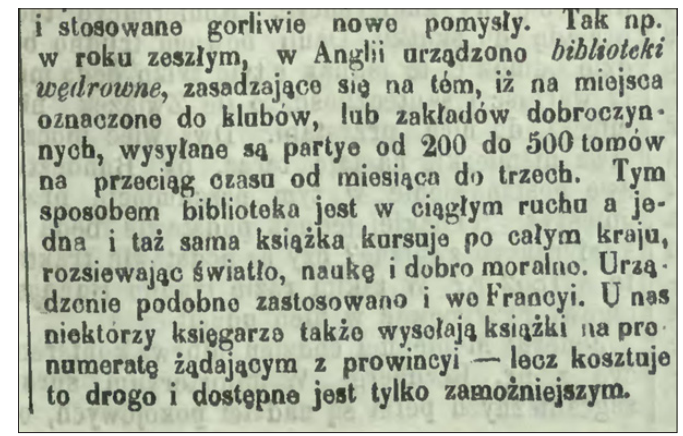

[Translation: ... Thus, travelling libraries were organized last year in England, on a principle that to the places assigned to clubs or charitable organizations, there would be sent collections of 200 to 500 volumes for a period of one to three months. In this fashion, the library is in constant motion, and a single book travels across the country, spreading light, science and moral good. A similar device was employed in France, too. In our country, some book-sellers send books to subscribers from a province - however, it is expensive and available only to the wealthy].

Source:

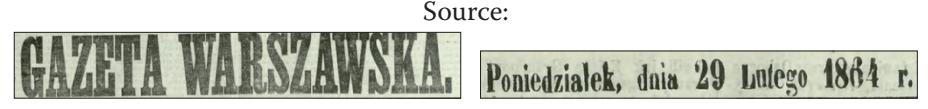

Gazeta Warszawska, Monday, 29 February, 1864.

Fig. 1. The example of of the phases ruchoma / wędrowna biblioteka (mobile / travelling library) 
Below are two examples related to the development of libraries from the second half of the nineteenth century and the first half of the twentieth century (Fig. 1 and Fig. 2).

As we said, digital libraries are constantly multiplying and therefore, the number of lexical units they archive has increased beyond estimation. Thus, there emerges another principle of the applied element of TLCH: the extraction of words will be optimized. A method for optimization has been included in the principles of the linguistic chronologization theory. Its formulation has three extraordinarily important effects: it makes possible a rapid identification and dating of lexical units; it lowers the cost; it allows for a highly precise verification of their accuracy. The question is, how to produce the largest possible dictionary comprising previously unrecorded units of a given language (e.g. Polish), of the most satisfying quality, in the shortest possible time and at the lowest possible cost.

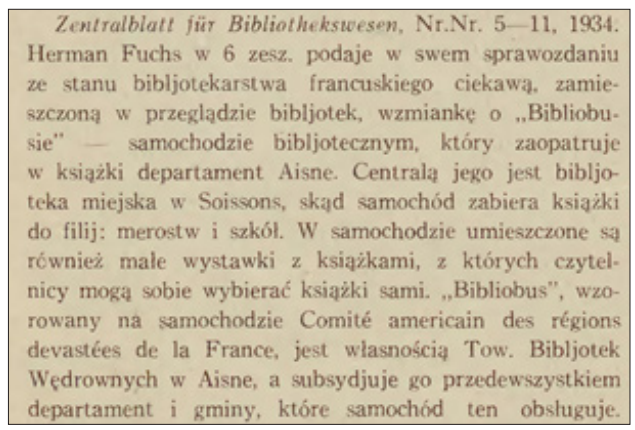

[Translation: ...Herman Fuchs in the sixth cahier provides, in his report on the state of French librarianship, an interesting mention, in the review of libraries, regarding a 'Bibliobus' - a library bus, which supplies with books the entire district of Aisne. It is based in the city library of Soissons, whence the vehicle takes the books to the library's branches: mairies and schools. In the car there is also a small collection of books to take away, from which the readers may choose themselves. 'Bibliobus', modelled on the car of Comité american des régiones devastées de la France is the property of the Association of the Travelling Libraries in Aisne, and it is funded primarily by the district and municipalities, which are served by this vehicle].

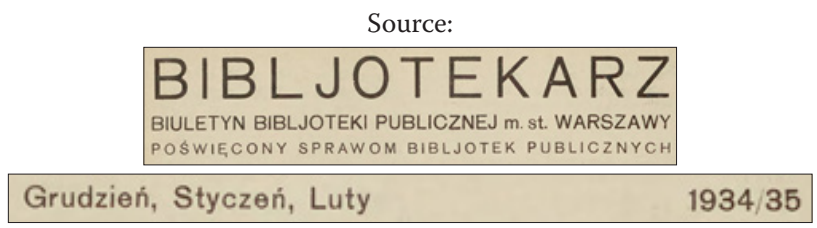

Bibljotekarz... December, January, February, 1934/35

Fig. 2. The documentation of the occurrence of the word bibliobus (bookmobile)

\section{The results of the research based on the TLCH}

The core component of the theory in its current state is the photo-documentation method, which makes possible a graphic presentation of the results of the analysis conducted basing on the TLCH. Thanks to this method, it is possible to present the result of linguistic chronologization analysis with the original context of the neologism. This method eliminates time-intensive and error-prone transcription. See for the three orthographic forms of the adjective anti-niemiecki, anty-niemiecki, antyniemiecki (anti-German) (Fig. 3). 


\section{anti-niemiecki}

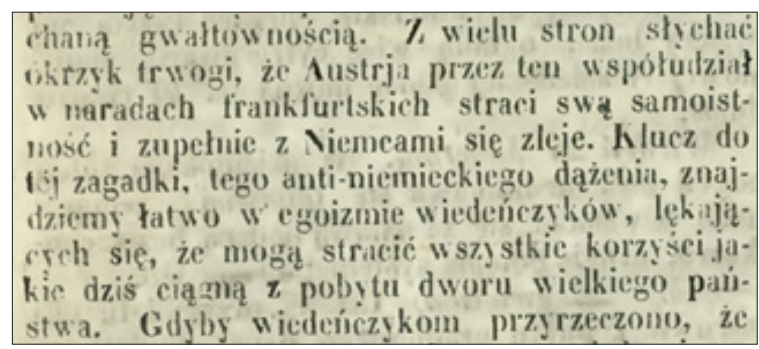

[Translation: ... From many corners there might be heard a cry of terror, that Austria, by its co-participation in the Frankfurt meetings will lose its identity and completely merge with Germany. The answer to this riddle, this anti-German aspiration, is to be easily found in the egoism of the Viennese, afraid that they may lose all the benefits from the presence of a great country's court they enjoy today].

anty-niemiecki

ternich. Ale Napjoleon lubi sie sam przeko-
nywaé o rzeczach; więc wybrał się z kondo-
lencyą do Salzburga, gdzie się przekonal, ze
Austrya nie na wiele mu się przyda w planach
anty-niemieckich. Więc też i Rouher i Lava-

[Translation: ... But Napoleon likes to see things for himself; therefore, he went to Salzburg with condolences, where he found out that Austria will not be of much help in his anty-German designs].

antyniemiecki

\begin{tabular}{|l|}
\hline \multicolumn{2}{|c|}{ AGITACYA ANTYNIEWIECKA. } \\
Peszt, 21 grudnia. (T· wl.) Agitacya anty \\
niemiecka nie nstaje. Wczoraj studenci wę- \\
gierscy urządzili wrogie manifestacye w tea- \\
trzykach niemieckich i zmusili włascicieli do \\
przyrzeczenia, że w ciągu miesiąca zaprowa- \\
dz̨̨ repertuar węgierski i będą dawali przed- \\
stawienia tylko w języku węgierskim.
\end{tabular}

[Translation: ANTYGERMAN AGITATION. Pest, 21 of December [the author's text]. Antygerman agitation does not cease. Yesterday the Hungarian students organized protests in German theatres and forced the owners to promise that before the month is over they will institute Hungarian repertoire and perform exclusively in Hungarian language].

Fig. 3. The documentation of the orthographic forms of adjective anti-niemiecki, anty-niemiecki, antyniemiecki (anti-German)

The presentation of this type is the basis of the National Photo-corpus of Polish Language (www.nfp.pl), which is described as follows:

The National Photo-corpus of Polish Language (NFJP) is a particular lexicographic enterprise. It takes up, in a new form and within a new methodological framework, a certain part of the tasks realized by the authors which, under the direction of Witold Doroszewski, created the eleven volumes of Stownik języka polskiego (Warszawa 1958-1969). (...)

But NFJP's collation of excerpts does not involve manual identification and transcription, typing up the occurrences of specific entries and sub-entries. NFJP employs photo-excerpts, prepares digital copies of extracts, guaranteeing a complete fidelity, which has an enormous significance for the description of language and the study of its development. 
The records gathered in NFJP and the work done on it, does not compete with any research program currently realized in Poland or anywhere in the world - it is completely beyond it. For more than 10 years, we have been discussing photo-lexicography; now, we are moving at an increasing speed towards photo-corpus linguistics. Currently, we are working (or, e-working) on source texts, the number of which is trebles that considered by Doroszewski's dictionary. In the near future, our collection of photo-excerpts will encompass c. 20000 bibliographic positions. Time has arrived for extensive excerption, aiming at total excerption, featuring all documents printed in the period between 1773 and the present day, created during the period (Wawrzyńczyk \& Wierzchoń, 2017, 3-4).
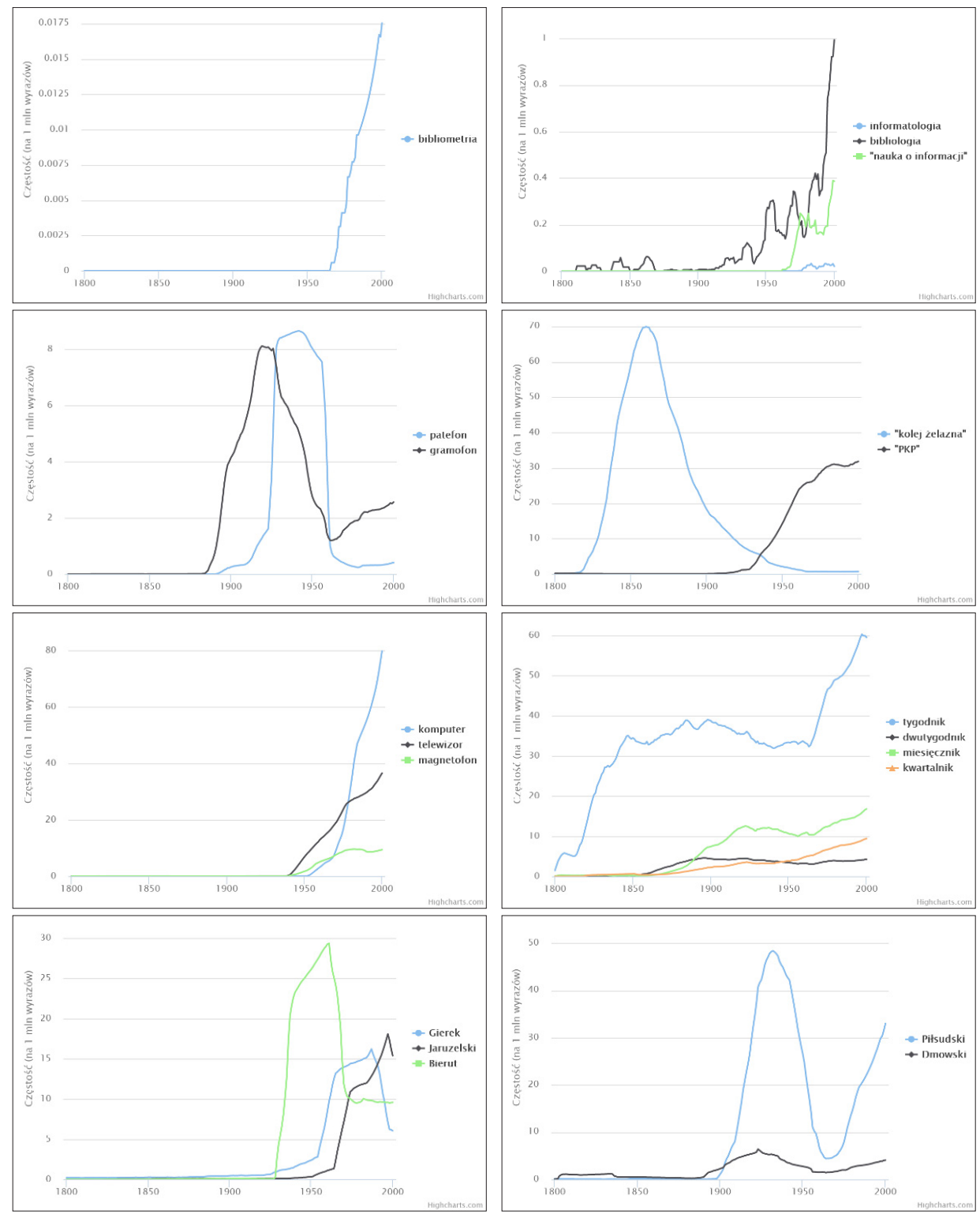

Fig. 4. The samples of diachronic curves generated by TLCH 
An important element of TLCH is the tool for tracking the frequency with which a given lexical unit occurred over time in the form of the so-called diachronic curve. Diachronic curves may describe the names of phenomena, ideas (words or word combinations), as well as proper names, e.g. of people (Fig. 4).

\section{Conclusions}

Linguistic chronologization theory (or, the photo-documentation method) is not only an example of interdisciplinary thinking but also (or, perhaps, primarily) of an enterprise which would be impossible, were the achievements of one discipline not implemented in the research undertaken within the framework of another. This was possible thanks to the extent of digitization of Polish libraries and to formulating a theory comprising an element of applied linguistics.

Tylko w tym sensie da się mówić o naukowej dyscyplinie zawodowej, którą wszakże
lepiej uznać i zorganizować jako spójną całość, niż traktować jako okolicznościową
sklejkę, konglomerat. Sposób powiązania tak rozumianej dyscypliny bywa różny
i w różnym stopniu zwarty. Rozprawia się w ostatnich czasach równie często
o specjalizacji (w sensie podziału dawniej jednolitych dyscyplin), jak i o inter-
dyscyplinarnosci i integracji nauk. Wszystkie te czynniki komplikują skrystalizo-
wanie zwłaszcza nowych dyscyplin, których społeczna potrzeba i aktualna celowość
dla ludzkości jest zupełnie oczywista i powszechna. Do takich właśnie dyscyplin
należy bibliotekoznawștwo.

[Translation: Only in this sense we may speak of a professional scientific discipline, which we would do better to consider and organize as a coherent whole, rather than as a contingent assemblage, conglomerate. The manner of binding thus defined discipline varies, as does the degree of its uniformity. Recently, we often discuss specialization (in the sense of division of previously uniform disciplines), as well as interdisciplinarity and integration of sciences. All these factors complicate the process of crystallizing, especially of the new disciplines, whose social need and actual relevance to humanity is completely obvious and general. It is to such disciplines that the library science belongs].

Source:

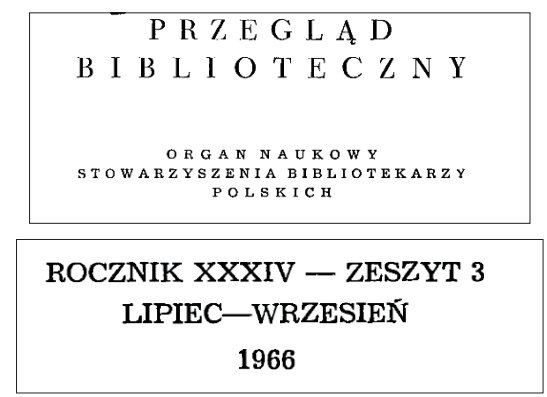

Przegląd Biblioteczny... 34.3 July-September, 1966.

Fig. 5. Photo-documentation for the term interdyscyplinarność ("interdyscyplinarity")

These successes were possible thanks to scholars who spent decades laboriously scanning library resources. However, TLCH borrowed from disciplines such as linguistics, information technology, artificial intelligence, history, media studies, library sciences, and so on. 
Finally, as we promised in the beginning of our article, we may pose a hypothesis regarding linguistic chronologization of the lexical unit interdyscyplinarność ("interdisciplinarity"). Photo - documentation and diachronic curve are presented in Figures 5 and 6.

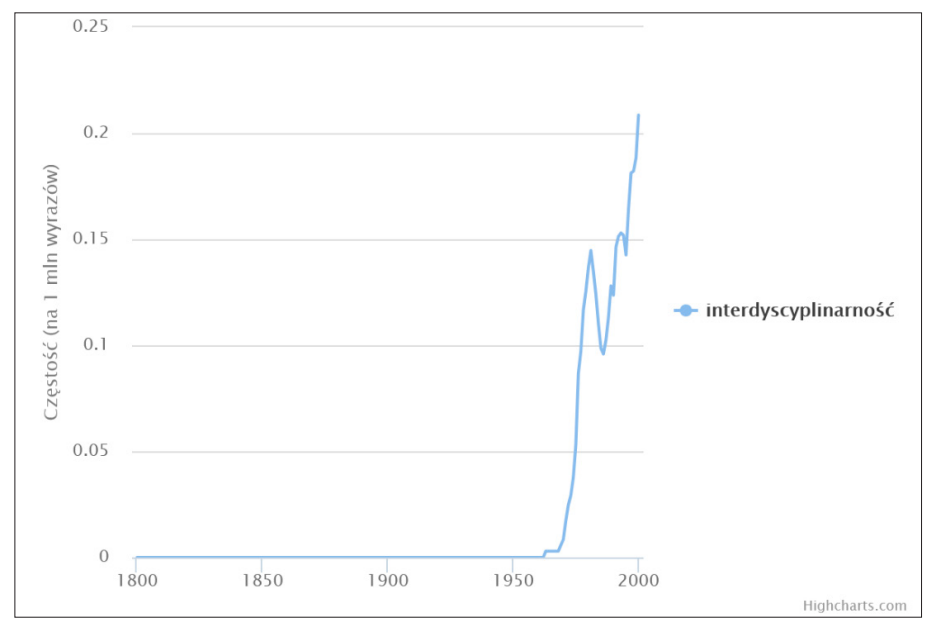

Fig. 6. Diachronic curve for the term interdyscyplinarność ("interdyscyplinarity")

\section{References}

FBC (n.d.). Federacja Bibliotek Cyfrowych [online], https://fbc.pionier.net.pl.

Jadacka, H. (2001). System stowotwórczy polszczyzny 1945-2000. Warszawa: Wydaw. Nauk. PWN.

Graliński, F. (2019). Against the Arrow of Time: Theory and Practice of Mining Massive Corpora of Polish Historical Texts for Linguistic and Historical Research. Poznań: Wydaw. Nauk. UAM.

Kowalska, M. (2006). Stan i perspektywy polskich zasobów cyfrowych w Internecie. Biuletyn EBIB [online], 11(81) [22.05.2020], http://www.ebib.pl/2006/81/a.php?kowalska

Osińska, V., Kowalska, M., Bednarek-Michalska, B., Malak, P. (2017). Czas uwolnienia zasobów a dynamika rozwoju i profil polskich bibliotek cyfrowych. Zagadnienia Naukoznawstwa, (1), 3-27.

Pawlicka, U. (2017). Humanistyka: pracownia, centrum czy laboratorium? Teksty Drugie, (1), 314-333.

Wawrzyńczyk, J. Wierzchoń, P. (2017). Podstawowe informacje o „Narodowym Fotokorpusie Języka Polskiego". Warszawa: Bel Studio.

Wierzchoń, P.(2008). Fotodokumentacja, chronologizacja, emendacja: teoria i praktyka weryfikacji materiatu leksykalnego w badaniach lingwistycznych. Poznań: Instytut Językoznawstwa UAM.

Wierzchoń, P. (2013). Jak badać słownictwo XX wieku dziś. 2008, 2009, 2010, 2011, 2012, 2013 - sześciolecie metody fotodokumentacyjnej. In: S. Puppel, T. Tomaszkiewicz (eds.), Scripta manent - res novae (557-568). Poznań: Wydaw. Nauk. UAM. 


\title{
Biblioteki cyfrowe i przełom w lingwochronologizacji. Zastosowania digitalizacji w językoznawstwie
}

\begin{abstract}
Abstrakt
Cel/Teza: Żywiołowy rozwój bibliotek cyfrowych w Polsce rozpoczął się na przełomie wieków. Zwiększenie łatwości dostępu zbiorów bibliotecznych nie było jedynym motywem i jednocześnie skutkiem ich upowszechnienia. Z perspektywy nauki o informacji funkcji bibliotek cyfrowych wymienić można zdecydowanie więcej, dlatego warto wskazać również na rolę, jaką biblioteki te spełniły w badaniach prowadzonych w ramach innych dyscyplin.

Koncepcja/Metoda badań: Artykuł ma charakter przeglądowo-opisowy. Jego autorzy skrótowo przedstawiają dotychczasowe wykorzystanie polskich bibliotek cyfrowych w językoznawstwie stosowanym, ściślej - w lingwochronologizacji, czyli datowaniu oraz redatowaniu neonimów, w naszym przypadku: dwudziestowiecznej polszczyzny.

Wyniki i wnioski: Z przeprowadzonej analizy wynika, że rozwój bibliotek cyfrowych był warunkiem sine qua non stworzenia nowoczesnej teorii lingwochronologizacji, którą można też traktować w terminach metody badawczej. Postęp w digitalizacji zbiorów bibliotecznych w przyszłości wpływać będzie na coraz wyższy stopień uprawdopodobnienia hipotez lingwochronologizacyjnych.

Oryginalność/Wartość poznawcza: Teoria lingwochronologizacji (TLCH) była wielokrotnie przywoływana w piśmiennictwie językoznawczym. Z informacji dostępnych autorom artykułu wynika, że nikt dotychczas nie podejmował problematyki wykorzystania bibliotek cyfrowych w językoznawstwie stosowanym na łamach czasopiśmiennictwa informatologicznego.
\end{abstract}

\section{Słowa kluczowe}

Biblioteki cyfrowe. Dygitalizacja zbiorów bibliotecznych. Językoznawstwo stosowane. Lingwochronologizacja. Nauka o informacji.

Dr hab. PIOTR NOWAK is Professor at Adam Mickiewicz University in Poznan, where he directs the Department of Infolinguistics at the Institute of Linguistics. He specializes in history of publishing, information science, and select aspects of language politics; he authored above a hundred publications, including monographs such as: Poznań jako ośrodek wydawniczy w dwudziestoleciu 1919-1939 (Poznań 1997), Wybrane problemy efektywności polskich czasopism naukowych z dziedziny humanistyki (Poznań 2000), Bibliometria. Webometria. Podstawy. Wybrane zastosowania (wyd. 1 Poznań 2006, wyd. 2 Poznań 2008), Cenzura wobec rynku książki. Wojewódzki Urząd Kontroli Prasy, Publikacji i Widowisk w Poznaniu w latach 1946-1955 (Poznań 2012), Kto w życiu myśli, nie pisze nic ... Krótka historia perlustracji w Polsce (Poznań 2016).

Contact to the Author:

pnowak@amu.edu.pl

Instytut Infolingwistyki

Uniwersytet im. A. Mickiewicza w Poznaniu

al. Niepodległości 4

61-874 Poznań, Poland

Prof. dr hab. PIOTR WIERZCHON directs the Department of Korean Philology at the Institute of Ethnolinguistics at Adam Mickiewicz University in Poznan. He specializes in general and applied linguistics; he authored above a hundred publications, including monographs such as: Anti (Poznań 2016), Antyafrodyzjak: rzeczowniki z członami inicjalnymi "anty-" $i$ „przeciw-” z lat trzydziestych dwudziestego wieku w obrazach i liczbach (Poznań 2016), Antykołchozowy: przymiotniki z członem inicjalnym "anty-" z lat trzydziestych dwudziestego wieku w obrazach i liczbach (Poznań 2016), Arcykomunistyczny: przymiotniki z członem inicjalnym "arcy-" z lat trzydziestych dwudziestego wieku w obrazach i liczbach (Poznań 2016), Arcywarchoł: rzeczowniki z członem inicjalnym „arcy-" z lat trzydziestych dwudziestego wieku w obrazach 
i liczbach (Poznań 2016), Autogloryfikacja: rzeczowniki z członem inicjalnym „auto-” z lat trzydziestych dwudziestego wieku w obrazach i liczbach (Poznań 2016), Depozytorium leksykalne języka polskiego: fotosuplement do Słownika warszawskiego. T. 11-40 (Warszawa 2015), Depozytorium leksykalne języka polskiego: fotosuplement do Słownika warszawskiego. T. 40 (Warszawa 2015), Depozytorium leksykalne języka polskiego: nowe fotomateriały z lat 1901-2010. T. 2 (Warszawa 2011), Depozytorium leksykalne języka polskiego: nowe fotomateriały z lat 1901-2010. T. 3 (Warszawa 2012), Dlaczego fotodokumentacja? Dlaczego chronologizacja? Dlaczego emendacja?: instalacja gazowa, parking podziemny i „odległość niezerowa” (Poznań 2008), Długodystansowiec: rzeczowniki z członem terminalnym „-owiec” z lat trzydziestych dwudziestego wieku w obrazach i liczbach (Poznań 2016), Fotodokumentacja, chronologizacja, emendacja: teoria i praktyka weryfikacji materiału leksykalnego w badaniach lingwistycznych (Poznań 2008), Fotosuplement do „Słownika warszawskiego”: indeks a fronte (Warszawa 2015), Gramatyka diakrytologiczna: studium ortograficzno-kwantytatywne (Poznań 2004), Indeks a tergo jednostek przekładowych Wielkiego słownika rosyjsko-polskiego z kluczem polsko-rosyjskim: porządek translandowy (Warszawa 2007), Indeks a tergo jednostek przekładowych Wielkiego słownika rosyjsko-polskiego z kluczem polsko-rosyjskim: porządek translatowy (Warszawa 2006), Jaskółki przejawów internacjonalizacji w słowotwórstwie współczesnej polszczyzny w materiałach z lat 1894-1984: tylko 100 przykładów (Łask 2008), Kotuś: „verba polona abscondita ..." (w fotodokumentacji): szkic lingwochronologizacyjny: centuria pierwsza (Poznań 2008), Polish digital libraries as a philologist's tool: based on 666 adjectives from the Digital Library of Wielkopolska (z: Mirosław Górny) (Poznań 2010), Półgłupek: rzeczowniki z członem inicjalnym „pół-” z lat trzydziestych dwudziestego wieku w obrazach i liczbach (Poznań 2016), Problem informacji frekwencyjnej w słowniku przekładowym (Łódź 2006), Radiomiłośnik: rzeczowniki z członem inicjalnym „radio-” $\mathrm{z}$ lat trzydziestych dwudziestego wieku w obrazach i liczbach (Poznań 2016), Słownictwo lat 30. XX w. w obrazach i liczbach: tylko 100 fotoprzykładów z „Depozytorium leksykalnego języka polskiego” i dużo wykresów z systemu „Odkrywka” (Warszawa 2015), Wczesnokapitalistyczny: przymiotniki z członami inicjalnymi „wczesno-", „późno-”, „szybko-” i „wolno-” z lat trzydziestych dwudziestego wieku w obrazach i liczbach (Poznań 2016), Z cudzysłowów do poczekalni leksykograficznej (Łódź 2003), Z cudzysłowów do poczekalni leksykograficznej II (Warszawa 2005).

Contact to the Author:

wierzch@amu.edu.pl

Instytut Etnolingwistyki

Uniwersytet im. A. Mickiewicza w Poznaniu

al. Niepodlegtości 4

61-874 Poznań, Poland 